\title{
The perceived barriers to the inclusion of rainwater harvesting systems by UK house building companies.
}

\author{
DAVID PARSONS*, STEVE GOODHEW**, ALAN FEWKES** AND PIETER DE WILDE***. \\ * Ridge and Partners, Beaumont House, 59 High Street, Theale, Reading, RG7 5AL \\ ** Nottingham Trent University, School of Architecture, Design and the Built Environment, Nottingham, NG1 4BU \\ *** University of Plymouth, School of Engineering, Environmental Building Group, Plymouth, Devon, PL4 8AA,
}

This work investigates the barriers that exist to deter the implementation of rainwater harvesting into new UK housing. A postal questionnaire was sent to a selection of large, medium and small house-builders distributed across the UK. Questions were asked concerning potential barriers to the inclusion of rainwater harvesting in homes separated into five sections; (1) institutional and regulatory gaps, (2) economic and financial constraints, (3) absence of incentives, (4) lack of information and technical knowledge, and (5) house-builder attitudes. The study concludes that although the knowledge of rainwater systems has increased these barriers are deterring house-builders from installing rainwater harvesting systems in new homes. It is further acknowledged that the implementation of rainwater harvesting will continue to be limited whilst these barriers remain and unless resolved, rainwater harvesting's potential to reduce the consumption of potable water in houses will continue to be limited.

Keywords: Rainwater harvesting; house builders; barriers; behaviour; perceptions

\section{Introduction}

The demand for water worldwide is increasing, together with concerns regarding our ability to secure global water resources for future generations. Acknowledged authors including Mee (2000) and Rose (2007) foresaw the impending problems, and have attempted to promote its importance. Of significance to this research is a statement from the International Union for the Conservation of Nature and Natural Resources (IUCN) (1980) 'World Conservation Strategy', urging that all future developments achieve "sound planning of water resources". In 2003 the UK government established the Sustainable Buildings Task Group to identify how government and industry could improve the quality and sustainability of new and refurbished buildings. The task group's report 'Better Buildings - Better Lives' (Department of Trade and Industry, 2004) concentrated on four areas, energy efficiency, renewable energy, minimising waste and water conservation. More recently the Code for Sustainable Homes produced by the Department of Communities and Local Government (DCLG, 2008), was introduced which requires all new homes to have a rating against the Code from 1st May 2008. The code introduces new minimum levels of performance in six key areas including water conservation indicating this is an integral element of sustainable construction. 
The collection of rainfall from the roof of a building, usually referred to as rainwater harvesting, and its subsequent use for non-potable applications, such as water closet (WC) flushing or garden watering, is a simple method of reducing the demand on the public water supply. Similarly, the collection of rainwater from roads and pavements, usually referred to as stormwater collection, can also be used to reduce the demand for potable water. In this article a structured postal questionnaire is used to investigate the current attitudes of a sample of UK house builders to the financial and practical viability of using rainwater harvesting systems in UK housing. The research presented in this article builds upon a similar survey carried out 10 years ago (Goodhew et al, 1999). It repeats a similar research effort one decade later, and contrasts the findings from the two pieces of research.

\section{Water resource management in the UK}

The UK is perceived as having an abundant supply of water available to satisfy its needs According to the World Resources Institute each person in England and Wales has 1400 $\mathrm{m}^{3} /$ year of water available, which is classified as a low availability rating (Griggs et al, 1997). However, water demand varies throughout the UK, with the largest demands in regions where there is least water available, for example, London $\left(250 \mathrm{~m}^{3} / \mathrm{year}\right)$ is categorised as having 'very low' water availability. The basic problem of water supply relates to the collection and storage to cover seasonal variation and the movement from areas where there is a surplus to areas where there is a shortage. Traditionally shortfalls in water supply have been satisfied by supply side solutions (supply management), which entails the development of new supplies and the provision of more treatment facilities.

An alternative approach to supply management is to use demand side solutions (demand management), that is, to examine the demand for water and consider ways in which to reduce water usage, examples include, water conservation devices, recycling and leakage control

\section{Factors affecting water use in the UK}

The average water usage in a UK home is approximately 145 litres/person/day but with significant variability linked broadly to affluence or socio-economic group. Water used in toilet cisterns represents around 30 per cent of water consumption for the average household. The bath and shower form the next largest contribution followed by washing machine usage. The collection and use of rainwater for WC flushing could result in approximately a one third reduction in the public water supply to the average household. Other non-potable uses which appear attractive are washing machine usage, and outdoor uses such as garden watering and vehicle washing. The use of rainwater for bathing and showering, without adequate treatment, represents a potential health risk because of the higher risk of accidental ingestion by the user.

Domestic water use has increased over the last two decades, in general per capita domestic water use is rising. Changes in water consumption are related to a number of factors such as, demographic changes, socioeconomic factors and climatic variation. Demographically, an increase or decrease in population results in a subsequent change in water usage. The population has been predicted to increase in the UK over the period 1997-2025 by 3.3 million (Environment Agency, 2001). 
The government's Sustainable Communities Plan, produced by the Office of the Deputy Prime Minister (ODPM) announced the number of homes constructed annually will increase to 209,000 , totaling an increase of 4.8 million homes by 2026 (ODPM,2006). The increasing number of dwellings is likely to be the key driver behind the growing demand for water (Arup and Leeds University, 2006). Therefore it is essential that all future housing developments adopt a cautious approach with regard to water resources (Environment Agency, 2006). However, with $60 \%$ of the planned growth being intended for construction in areas already suffering from water scarcity such as the southeast of the UK, it is expected that as a result the use of water situation locally and UK wide will become more critical. This notion is sustained by the ODPM (2005) envisaging as a consequence of this growth, an increase of $728,000 \mathrm{~m}^{3} /$ day in the demand for water by 2016 , and a further increase in demand of $1,102,000 \mathrm{~m}^{3} /$ day by 2031 , thus confirming previous expectations presented by the National Rivers Authority (NRA) (1994) and the Department for Environment, Food and Rural Affairs (DEFRA) (2002).

\section{The use of Rainwater Harvesting Systems in developed countries}

The use of rainwater harvesting systems to supply non-potable water to buildings during the last 15-20 years has become popular in urban areas of some developed countries. Berndtsson (2004) suggests the UK house-building sector is falling behind other countries who are now embracing domestic rainwater harvesting on a large scale. Brown et al (2005) and the Environment Agency (2003) identified successes in Germany and Australia and suggested that the UK should strive to encourage a similar uptake in the future

The potential of rainwater systems became apparent in Germany during the period $1970-$ 75 when this country experienced several problems with the management of its water supply and sewerage systems. Initially to promote the use of rainwater systems many city councils offered financial incentives. The current trend is to divide charges for urban drainage into two components. One related to consumption dependent waste water discharges and the other linked to the impervious surface area of the property. A permanent financial incentive therefore exists to disconnect roofs from sewers (Herman \& Schmida, 1999). In Europe, Germany is leading the way with the installation of rainwater collection systems. It is now estimated approximately 50,000 rainwater harvesting systems are installed in Germany each year, mainly in new housing (Nolde, 2006). Konig (2007) documents the use of rainwater harvesting systems in a variety of buildings, including the filtration of rain run off by means of vegetated earth filters in the intake to the rainwater collection tank. Other novel approaches being investigated by German researchers includes the use of more polluted stormwater which is treated before reuse in washing machines and $\mathrm{WC}$ flushing (Nolde, 2006)

In other parts of Europe the use of rainwater harvesting systems is not well developed. In Italy for example a recent survey (Pacrarotti, et al, 2007) revealed only $7.6 \%$ of companies contacted had installed systems. The majority of these companies had only started installing rainwater systems during the last eight years but had undergone or expected an increase in demand. Consumer knowledge and perceptions coupled with a lack of design guidance were identified as significant barriers to the development of the market in Italy.

In Scandanavia research (Villarreal and Dixon, 2005) has identified the vulnerability of Sweden's large scale centralised water supply which is attributable mainly to increased urbanisation. Rainwater harvesting has been identified as one strategy which could be used 
to reduce the amount of water required from the public water supply system for urban developments

Australia encourages the widespread use of rainwater harvesting and has demonstrated the benefits of these systems. Encouragement was principally through grant aid coupled with new regulations relating to health issues and plumbing installations (Cunnliffe, 2004). Since regulatory issues were resolved and incentives introduced, the use of rainwater harvesting has considerably increased, and 245 tanks were installed totaling 1.67 million $\mathrm{m}^{3}$ in Canberra alone during 2003-04 (Tranter, 2004). Chanan and Woods (2006) reported similar successes in Kogarah (Sydney), where rainwater utilised for all non-potable applications in new housing and schools has resulted in savings of 150 million $\mathrm{m}^{3}$ of potable water annually.

Examples of rainwater harvesting systems are now not only common in rural ares but also urban areas due to the adoption during the last decade, by all levels of government in Australia, of the concept of ecologically sustainable design. This includes Water Sensitive Urban Design (WSUD) which recognizes the role rainwater harvesting can have in substituting and/or supplementing reticulated urban water supply from centralised water supply facilities (Mitchell, 2004). In addition rainwater harvesting has the potential to reduce the volume of stormwater discharge and reduce peak run off rates (Coombes et al, 2002). Research has also demonstrated the economic viability of rainwater harvesting systems at both local and regional scales (Coombes et al, 2000).

In New Zealand it is estimated more than $10 \%$ of the population uses rainwater harvesting for their drinking water. The main users are rural communities not supplied by centralized systems. A recent study (Abbott et al, 2007) has investigated the microbiological quality of roof collected rainwater. Samples were collected over a five year period from 560 private dwellings. High levels of faecal contamination suggests information on the safe collection and storage of roof collected rainwater is not reaching or being practiced by many users in New Zealand.

Research into rainwater harvesting systems tends to focus on water savings, water quality and stormwater control but rarely considers the wider environmental issues such as sustainable resource use. A life cycle analysis comparing rainwater harvesting systems and centralized reticulated supply undertaken for urban houses in Auckland, New Zealand (Mithraratne and Vale, 2007). This study indicates rainwater harvesting may not be the most sustainable option in all situations. The rainwater collection tank material was identified as being important, concrete tanks offer a more sustainable option than plastic tanks.

Rainwater harvesting systems are used in at least a dozen US states and territories. It is estimated there are over 100,000 systems in operation. Texas is an example of a state which has experienced growth in the use of rainwater harvesting systems over the past ten to fifteen years where it is estimated 15,000 systems are now in operation. The growth is related to climatic conditions and continuing population growth but has been further assisted by governmental incentives and improved literature relating to the design and operation of systems (Krishna, 2007). In addition, the US Green Building Council's environmental assessment method (LEED) for buildings, gives credits for a range of building design initiatives, including rainwater harvesting. 
In Canada rainwater harvesting systems have been used in rural areas for more than fifty years. For example, in Nova Scotia, rainwater is used as an alternative drinking water source where ground supplies are inadequate or contaminated. The Nova Scotia Department of Health have published guidelines for system operation and construction

(Scott and Waller, 1991). In the urban context the Research Division of Canada Mortgage and Housing Corporation have sponsored the design of the Toronto Healthy House which is completely independent of municipal water and waste water services. Potable water is supplied by a rainwater harvesting system and all wastewater is recycled for non-potable uses (Townsend, 1997)

Rainwater harvesting could have a significant future role in reducing domestic water consumption in the UK, and consequently in reducing the demand for potable water. However it has been suggested that there is a significant shortage of interest in installing the systems within the house-building sector, and that the technology is being ignored and too readily dismissed (Heggen, 2000; Leggett and Shaffer, 2002). These views echo previous research undertaken by Goodhew et al, (1999), where nearly a decade ago it was illustrated that amongst house-builders there was a lack of uptake and interest in water conservation measures in domestic buildings.

The reality of rainwater harvesting not being widely employed was first recognised by Smerdon, Wagget \& Grey (1997). Rainwater systems in the UK are not new, and a lack of use was highlighted in 2001 where only 75 successful and operational domestic systems were identified in the UK (Diaper, Jefferson, Parsons and Judd, 2001). Hunt and Rogers (2005) agree that the number of installations has increased in recent years since Diaper et al's (2001) research, but suggests rainwater harvesting is still not being widely adopted in standard housing developments, and only integrated into isolated projects.

\section{Key barriers towards the potential uptake of rainwater harvesting}

Suzenet et al (2002) have identified the key barriers towards the potential uptake of rainwater harvesting which are: lack of information and knowledge; economic and financial constraints; absence of incentives; institutional and regulatory gaps; house-builder attitudes. As a potential barrier to rainwater harvesting, the attitudes of developers towards integrating measures linked to sustainable living, ranging from energy efficiency to recycling related actions into new homes may be key. Goodhew et al (1999) identified a negative attitude amongst house-builders towards the issue of sustainability and the environment. Similarly Sponge (2005) suggests building sustainable homes is not a high priority to private sector house-builders. Edwards (2005) also notes the industry's significant past and current lack of focus towards water conservation issues. As an example in 2002 Essex and Suffolk Water funded a scheme to install water efficient technology into new housing. The scheme came at no extra cost and was open to all developers, yet was only adopted by one developer (Read, 2005). John Slaughter of the House Builders Federation (HBF) reinforces the perceived attitude of developers who commented that water conservation features "fairly low down the list" of house-builders priorities (House of Lords, 2006).

The sustainability of new housing has been previously encouraged and measured through the voluntary Building Research Establishments (BRE) EcoHomes scheme. BRE and Sweett (2005) reported a low uptake of EcoHomes by house-builders. However the situation is set to change because the BRE EcoHomes scheme was replaced in April 2007 by the Code for 
Sustainable Homes (BRE, 2006). From 1 May 2008 a rating against the Code will become mandatory for all new homes. The Code is an environmental assessment method for new homes based upon EcoHomes and introduces minimum performance levels in 6 key areas; energy efficiency/ $\mathrm{CO}_{2}$ emissions; water efficiency; surface water management; site waste management; household waste management; use of materials.

This article assesses the suggestions that house-builders currently have a limited interest in rainwater harvesting, and as a consequence the systems potential to conserve potable water is being lost. The primary aim of this research intends to investigate what perceived or real barriers exist, and to assess to what extent each deters the implementation of rainwater harvesting in new housing. The issue of rainwater harvesting systems in refurbished properties is not considered in this study.

\section{Methodology}

The methodology for the survey presented in this work (described in this text as the recent survey) follows the main methods used by the survey undertaken approximately 10 years ago, (described in this text as the previous survey)a postal questionnaire. The selection technique is updated by utilizing electronic sources and more narrowly focuses upon rainwater harvesting, rather than including other water saving measures as this term has become more common parlance than a decade ago.

A sample of 100 house building companies from a wide geographical distribution across the UK were selected using the UK House-builders Directory on the internet (2007), a comprehensive website providing contact information for house-builders in varying geographical locations in the UK. To ensure that each element in the population had an 'equal and independent' chance of being selected, companies were picked from the initial groups by using a random sample selection technique. Once the sample had been selected, a preliminary telephone call was made to each company, to confirm that they would be willing to participate in the research to aid maximising the response rate.

As a questionnaire was previously used (Goodhew et al, 1999), a decade ago, to contact a range of UK house builders, the same method was used for this research. Some questions were adapted from the previous questionnaire to allow appropriate comparisons between both sets of findings.

The first section of the questionnaire relies upon a series of closed questions requesting data that will identify the type and size of the house building company. Further major categories of questioning included requests for information concerning industry, uptake of rainwater harvesting systems, knowledge of rainwater storage, financial considerations and enquiries into the use of possible incentives.

A further section considers 'financial considerations' aiming to determine whether the expenditure required to install a rainwater harvesting system is a barrier to its application in new homes. These questions also attempted to ascertain whether or not respondents felt that installing rainwater harvesting would create a marketing opportunity, (Mulholland, 2004) 
Questions concerning incentives link to the anticipated findings from the 'financial considerations' questions in an attempt to discover whether the lack of incentives/grants available for rainwater harvesting is an issue, and if grants were introduced, whether it would increase the respondent's use of rainwater harvesting.

The aspect of regulatory control was investigated through requests of the respondents to judge whether in their view any current lack of legislation governing rainwater harvesting is an issue, and if so, where new legislation would be required to increase the use of rainwater harvesting systems in new buildings.

Respondents were encouraged to comment in more general terms concerning related issues or where they felt that their responses could be elaborated upon. Some of these comments are included in the results and conclusion sections of this work.

\section{Results}

The results are presented under the same broad categories and themes adopted in the questionnaire. Not all of the responses to the questions are presented in the interests of brevity. From the total of 100 questionnaires 46 were returned, 12 of the respondents were small companies, 20 were medium and the remaining 14 were large organisations. The original survey was undertaken in 1998 and published in 1999, (Goodhew et al, 1999). 50 questionnaires were returned compared to the 46 of the 2007/8 survey. The earlier survey used the National House Building Council (NHBC) database to select equal number of small medium and large registered house builders. The respondents matched the relatively even spread of company size found in the returns of the more modern survey. With the improvements in survey techniques including the recent improvements in online surveys the more modern survey could have been undertaken electronically. However, the methodologies for the two surveys were intentionally very similar (both postal questionnaires to selected house buildings of different sizes) allowing direct comparison in most aspects. This probably reduced the number of respondents in the second survey, but as the numbers of respondents were approximately the same, this was not felt to be particularly limiting.

\section{Industry Uptake and Knowledge}

To assess the perceived level of importance regarding varying environmental issues, respondents were requested to rate each issue from 1.0 (unimportant) to 5.0 (very important) with regards to their new housing developments. The results demonstrated that 25 respondents perceive energy as highly important and consequently the most significant environmental aspect. Waste and pollution were ranked secondly important whilst water was considered least important. Figure 1 displays the results, indicating the number of responses received for each issue and its perceived level of importance.

From the mean scores on perception of importance of environmental category (Energy, Water, Waste, Pollution), the variances were equal, F $(3,180)=0.579$, ns. A one-way ANOVA showed that there was a significant main effect of category on the perception of importance scores, $\mathrm{F}(3,180)=3.24, \mathrm{p}=<0.05$. This shows that there were genuine differences in the respondents' attitudes to each of the four categories. In order to identify where the differences in perception between water and each of the other categories a further Post hoc test was carried out. This confirmed that the differences between the 
perception of the importance of water as compared with energy $(d=1.27)$, water compared with waste $(d=0.75)$ and water compared with pollution were unlikely to have arisen by sampling error $(d=0.69)$ and therefore are not chance findings.

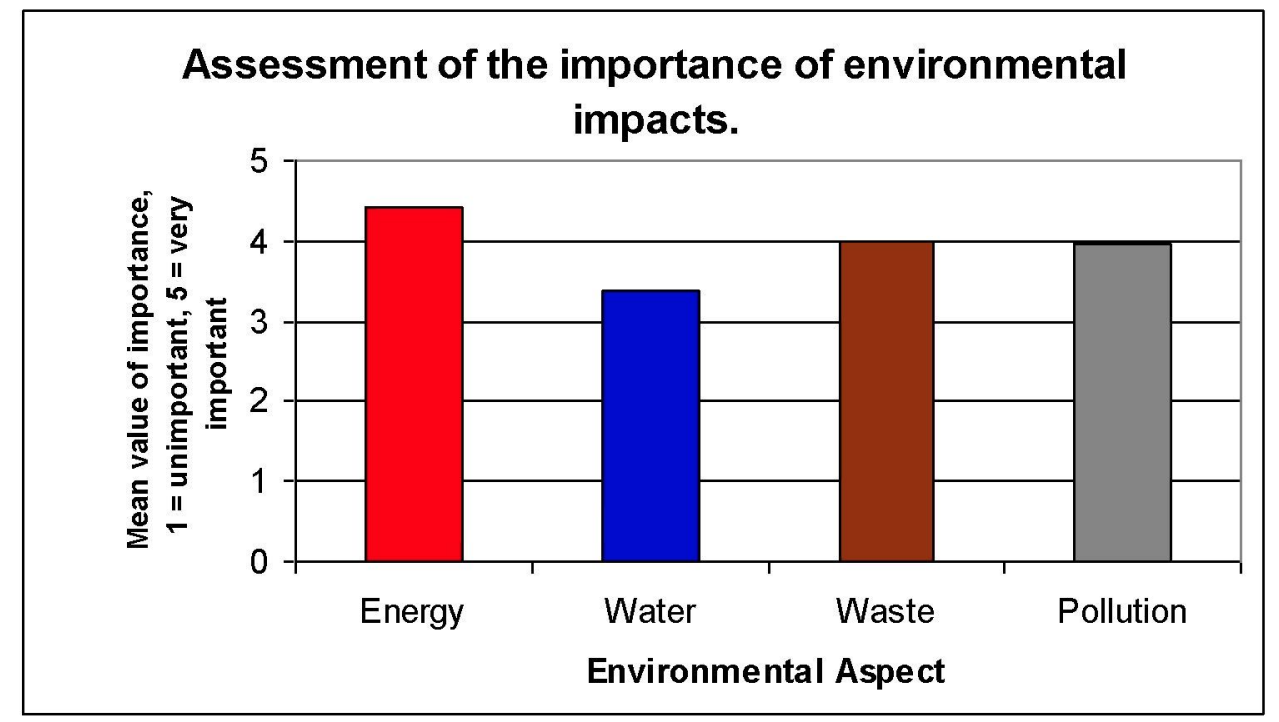

Figure 1: Importance of Environmental Aspects in New Developments.

The respondent's awareness of rainwater harvesting was assessed. Only one company had no knowledge of rainwater harvesting. In a related question, respondents were questioned as to what extent rainwater harvesting had been included into their new developments over the past five years. The results display a low inclusion rate of rainwater harvesting, with $76 \%$ respondents never having used the technology, 9 incorporated it into less than $25 \%$ of projects, and only 2 have installed it into $25-50 \%$ of developments. None of the respondents reported incorporating rainwater harvesting in over $50 \%$ of developments. This can be contrasted with the previous survey, where $96 \%$ of respondents had not installed rainwater systems.

The majority of respondents reported having a poor/moderate level of technical knowledge. $52 \%$ of respondents reported having a moderate knowledge, $33 \%$ showed a poor understanding, and only $15 \%$ of the respondents reported having a good/very good level of technical knowledge. This can be compared with the previous survey where $44 \%$ of house builders had no knowledge of rainwater or greywater systems.

Generally levels of technical knowledge regarding rainwater systems varies considerably. The majority of respondents, 31, felt that their level of technical knowledge was insufficient to confidently incorporate rainwater harvesting into one of their properties whilst 15 stated that it was sufficient.

\section{$\underline{\text { Financial Considerations }}$}

Using data from several of the prominent specialist installers and providers it was estimated that at the time of the survey $07 / 08$, it cost between $£ 1500$ and $£ 2500$ to fully install an individual rainwater harvesting system into a new dwelling. The results illustrate that 30 respondents would not be willing to incur the additional costs, whilst 16 respondents $(35 \%)$ stated they would. This can be contrasted with the previous survey where $22 \%$ of respondents would be willing to install a system using equivalent costs. 
A study performed by Mulholland Research and Consulting (2004) revealed that,

" $87 \%$ of new home-buyers want to know how their homes rate in terms of environmental performance in order to make an informed purchase decision, 48\% regarded water efficiency as an important factor"

Respondents were asked to consider the above statement and to express whether they agree that installing a rainwater system could potentially increase both house sales and prices. $54 \%$ respondents disagreed, $12 \%$ could form no judgment, and $20 \%$ agreed that in essence it could create a marketing edge. The previous survey noted that $76 \%$ of respondents did not feel that including rainwater or greywater recycling systems would increase their sales.

\section{$\underline{\text { Incentives }}$}

The respondents were asked whether they supported the introduction of incentives or grants to support the use of rainwater systems and how much should the incentive be if it is to influence the decision to use such a system.

The results shown in Figure 2 indicate that the issue of absent incentives is significant, with $87 \%$ of respondents reporting that the introduction of incentives would increase their use of rainwater harvesting, and $13 \%$ stating it would not. Respondents, who believed incentives were essential, were subsequently requested to indicate the level of grant that would be required. The majority of respondents, over $50 \%$, indicated that a grant of $£ 751-£ 1000$ would be sufficient

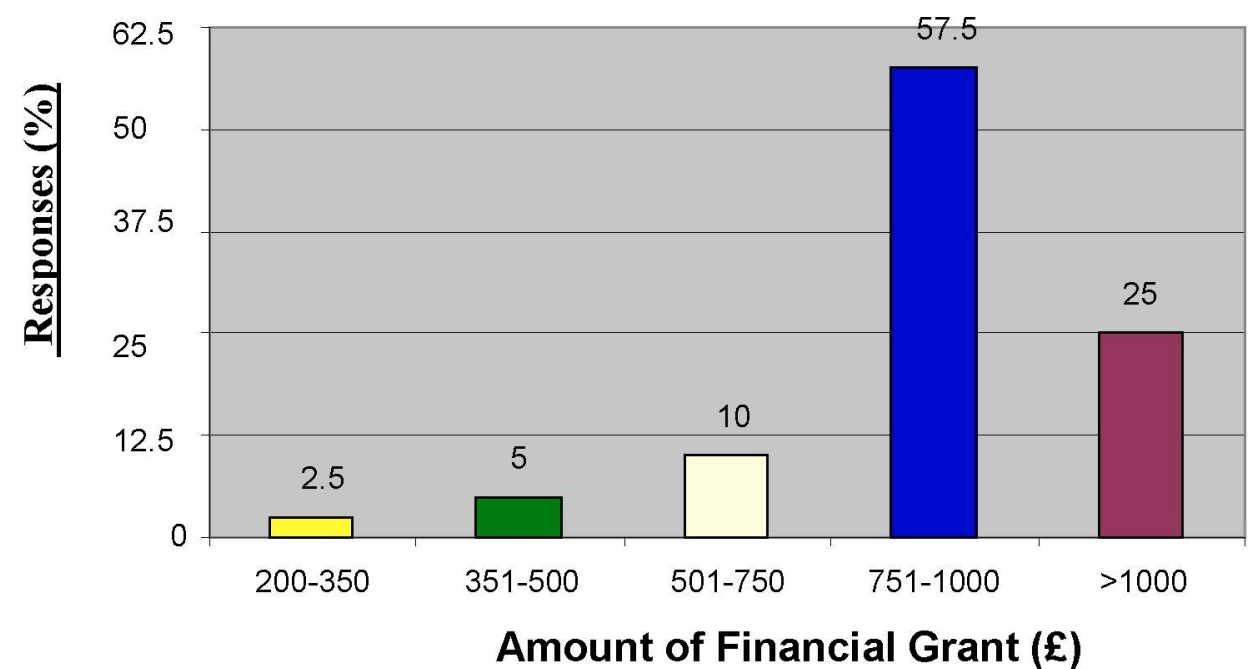

Figure 2: Amount of financial grant required to increase use of rainwater harvesting. 


\section{$\underline{\text { Regulations }}$}

The recent survey asked the house builders whether any change to current regulations in three related areas, water quality standards, design and installation of rainwater systems in homes would have an influence of their uptake.

A total of 44 out of 46 respondents considered new and clearer legislation governing rainwater harvesting systems would aid the increase in its uptake in the future. A chisquare test of goodness-of-fit determined that responses were not equally distributed and that there was a preference for new legislation $\left(\chi^{2}=38.5, d f=1, p<0.01\right)$. Participants who deemed new regulations as helpful were further requested to indicate where the legislation would be required. The results in Figure 3 show there is a slight (but not significant) preference in relation to new design and construction legislation as indicated by 40 respondents for this category, followed by installation and plumbing as indicated by 38 respondents. A further 32 respondents also felt and indicated that new regulations would be required to regulate water quality from rainwater systems.

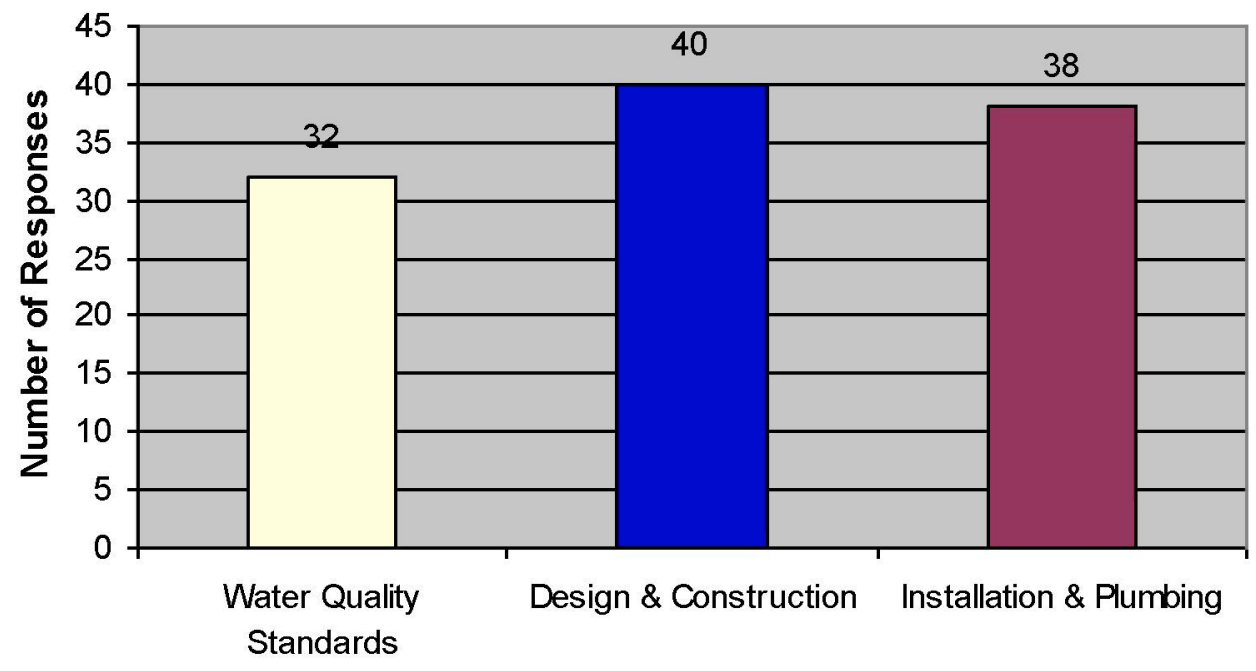

Areas of Regulation

Figure 3: Areas in which new regulations are required.

\section{The two surveys}

The data from two surveys used are felt to be robust and offers an appropriate basis for comparison. Both surveys have use equivalent methodologies and questioning that is comparable bearing in mind the advances and changes that have taken place over the approximate 10 year span between the surveys being undertaken.

In the recent study $67 \%$ of the studies respondents considered they had inadequate level of technical knowledge to be able to confidently install a rainwater harvesting system. However, only $33 \%$ of respondents indicated that their knowledge was poor with no companies stating that they had a very poor understanding. This indicates that house buildings have a better knowledge base when compared with the previous survey, where $44 \%$ of house builders had no knowledge of rainwater or greywater systems. 
$76 \%$ of the respondents of the recent survey stated that they have never installed rainwater systems into their new housing developments over the past 5 years. Whilst this percentage reflect a low uptake it reflects an increase in uptake compared to the $96 \%$ of house building companies who had not installed rainwater systems approximately a decade ago.

In the recent survey $35 \%$, of the respondents were willing to incur the expenditure required to install a rainwater harvesting system. This is an increase when compared with the previous survey, where $22 \%$ of respondents would be willing to install a system at extra cost and follows the general pattern showing a gradual increase of knowledge, use and awareness of the cost of rainwater systems in newly built houses and the related contracting companies.

\section{Discussion and Conclusions}

House-builders still have a poor level of technical knowledge relating to rainwater harvesting systems but this has improved, abeit from a low base over the 10 years between the surveys. Coupled with the lack of impartial guidance relating to the design and installation of rainwater harvesting systems this is a barrier to the rate at which systems are installed in new housing developments.

Publications including 'Rainwater and Greywater use in buildings: Best practice' (Leggett et al, 2001) have attempted to answer house-builders technical queries; however the publications themselves acknowledge that they cannot provide all of the required information. Manufacturer's information is in abundance; however, the enthusiasm to promote their respective product potentially portrays this source of information in a favorable light. The new British Standard, BS8515:2009 may well be the instrument to offer technical guidance to UK house builders concerning rainwater systems in UK housing.

From the surveyed house builders it can be concluded that there is still a limited use of rainwater harvesting systems in new homes constructed in the UK and as a consequence the ability of these systems to reduce both water demand and consumption at domestic and national levels is being lost. Domestic activities consume considerable amounts of potable water with $33.5 \%$ of consumption being attributed to WC usage, whilst a lower quality grade of water is adequate for this purpose. Studies presented by Fewkes (1999) and Horton (2005), demonstrate that if rainwater harvesting is used for these lower quality water applications, potable water consumption would be reduced thus easing the impact that new homes will have upon future water demand. Rainwater harvesting systems will also reduce the rate of rainwater runoff from roofs and contribute positively to a sustainable urban drainage (SUDS) design strategy.

Financial and economic constraints are a barrier to the installation of rainwater harvesting systems in new UK houses and will remain until governmental incentives are introduced. Financial barriers are significant. It was not surprising therefore that $87 \%$ of respondents to the recent survey reported that the introduction of grants would encourage their use of rainwater harvesting. Until incentives are introduced to help "bridge the gap in costs" as one respondent states, the use of rainwater harvesting in new homes likely to be limited. 
The lack of legislation regulating domestic rainwater harvesting systems is a barrier deterring the installation of systems into UK houses. In the recent survey $96 \%$ of respondents indicated that new/clearer legislation would be required to increase their future use of rainwater harvesting. All the areas of water quality, design and construction, and installation and plumbing were identified as being appropriate for legislation. This is reinforced by comments from the respondents that included "It is unlikely that any volume builder will include rainwater systems without regulatory backing governing design and construction". Given the low uptake of rainwater systems, regulation might be needed, as without new legislation the use of rainwater harvesting amongst house-builders is very likely to remain restricted.

Through comparison between the surveys described in this work, it is evident that the expectation of increasing awareness of rainwater harvesting's existence amongst housebuilders has been confirmed. The key observations derived from the comparison are that during the last decade the knowledge base has improved but not markedly. The use of rainwater harvesting amongst house-builders has remained consistently low and that financial barriers identified a decade ago are still a significant barrier deterring its use amongst today's house-builders.

\section{REFERENCES}

Abbott, S., Caughley, B. and Douwes, J. (2007) The microbiological quality of roof collected rainwater of private dwellings in New Zealand. In Proceedings of the Rainwater and Urban Design Conference, Sydney, Australia, $21-23$ August.

Arup and Leeds University (2006) Written evidence for House of Lords Science and Technology - Eighth Report. [Online] Available at:

http://www.publications.parliament.uk/pa/ld200506/ldselect/ldsctech/191/191we03.htm. [Accessed 30th April 2009].

Berndtsson, J. (2004) Beneficial use of stormwater: A review of possibilities. Gothenburg, Sweden. Chalmers University of Technology.

BRE and Sweett, C. (2005) Information Paper IP 4/05: Costing Sustainability - How much does it cost to achieve BREEAM and EcoHomes rating. Watford. BRE.

BRE (2006) Press Release 13 December 2006: BRE welcomes the new code for sustainable homes. [Online] Available at: http://www.bre.co.uk/newsdetails.jsp?id=422. [Accessed 30 $0^{\text {th }}$ April 2009].

Brown, R,R., Sharp, L. and Ashley, R.M. (2005) Implementation impediments to institutionalising the practice of sustainable urban water management. Presented at the $10^{\text {th }}$ International Conference on Urban Drainage. Copenhagen, 21-26 August 2005. pp1-8.

Chanan, A. and Woods, P. (2006) Introducing total water cycle management in Sydney: A Kogarah Council initiative. Desalination. Vol,187. pp11-16.

Coombes, P.J., Kuczera, G. and Kalma, J.D. (2000) Economic benefits arising from use of water sensitive urban development source control measures. $3^{\text {rd }}$ International Hydrology and Water Resource Symposium, Perth, Australia, pp $152-157$.

Coombes,P.J., Kuczera, J.D., and Argue, J.R. (2002) An evaluation of the benefits of source control measures at the regional scale. Urban Water. Vol. 4. Iss. 4. pp 307-320.

Cunliffe, D.A. (2004) Guidance on the use of rainwater tanks. EN Health Council. Department of Health and Ageing. Australian Government. 
DCLG, (2008) Code for Sustainable Homes: Technical guide. (Accessed 30 ${ }^{\text {th }}$ April 2009 http://www.communities.gov.uk/publications/planningandbuilding/codeguide)

DEFRA. (2002). Directing the Flow: Priorities for Future Water Policy. London. Department for Environment, Food and Rural Affairs.

Diaper, C. Jefferson, B. Parsons, S,A and Judd, S (2001) Water Recycling Technologies in the UK. Journal of the Chartered Institution of Water and Environmental Management (CIWEM). Vol,15. Iss,4. pp282-286.

Edwards, B. (2005) Rough guide to sustainability. Second Edition. RIBA. London.

Environment Agency. (2001). Water Resources for the Future: A Strategy for England and Wales. Bristol. Environment Agency.

Environment Agency. (2003) Harvesting rainwater for domestic uses: An information guide. Environment Agency. Bristol.

Environment Agency (2006) Environmental Facts and Figures: Sustainable Communities. [Online] Available at http://www.environment-agency.gov.uk/research/library/data/34331.aspx. [Accessed 30th April 2009].

Fewkes, A. (1999) The use of rainwater for WC flushing: The field testing of a collection system. Building and Environment. Vol,34. pp765-772.

Goodhew, S., Fititzgerald, D. and Southcombe, C., (1999), Water efficient dwellings; Do UK house builders recognise a need?, Journal of Financial Management of Property and Construction, 4(2), 49-62.

Griggs, J.C., Shouler, M.C. and Hall, J. (1997) Water Conservation and the built environment. In Architectural digest for the 21st century. Ed. Roaf, S., School of Architecture, Oxford Brookes University, Oxford.

Heggen, R,J. (2000) Rainwater catchment and the challenges of sustainable development. Water Science and Technology. Vol.42. Iss.1-2. pp141-145.

Herrington, P. (2006). The economics of water demand management. In water demand management, Butler, D., and Memon, F. A. (Ed), IWA Publishing, London.

Herrmann, T. and Schmida, U. (1999) Rainwater utilisation in Germany: efficiency, dimensioning, hydraulic and environmental aspects. Urban Water 1(4), 307-16.

Horton, B. (2005) Sustainable Homes - The financial and environmental benefits. Bristol. Environment Agency.

House of Lords (2006) Science and Technology - Eighth Report. Prepared $6^{\text {th }}$ June 2006. [Online] Available at: http://www.publications.parliament.uk/pa/ld200506/ldselect/ldsctech/191/19102.htm. [Accessed 30th April 2009].

Hunt, D and Rogers, C. (2005) Barriers to sustainable infrastructure in urban regeneration. Proceedings of the Institution of Civil Engineers: Engineering Sustainability. Vol,158. Iss,June ES2. pp67-81.

IUCN (International Union for the Conservation of Nature and Natural Resources). (1980). World Conservation Strategy. Gland, Switzerland. IUCN.

Konig, K.W. (2007) Rainwater management facilities devices: Case studies in Germany. In Proceedings of the Rainwater and Urban Design Conference, Sydney, Australia, 21 - 23 August.

Krishna, J.K. (2007) Development of alternative water resources in the USA: Progress with rainwater harvesting. In Proceedings of the Rainwater and Urban Design Conference, Sydney, Australia, $21-23$ August. 
Leggett, D,J. Brown, R. Brewer, D. Stanfield, G. and Holliday, E. (2001) Rainwater and Greywater use in buildings: Best practice guidance. CIRIA. London.

Leggett, D,J and Shaffer, P. (2002) Buildings that save water - Rainwater and greywater use. Proceedings of the Institution of Civil Engineers: Municipal Engineer. Vol.151. Iss.3. pp189-196.

Mee, L. (2000) BBC News 12 January 2000: Scientists analysis water crisis. [Online] Available at: http://news.bbc.co.uk/1/hi/sci/tech/599061.stm. [Accessed 30th April 2009].

Mitchell, V.G. (2004). Intergrated urban water management: a review of current Australian practice. AWA/CSIRO. CMIT-2004-075.

Mithraratne,N. and Vale, R. (2007) Rain tanks or reticulated water supply. In Proceedings of the Rainwater and Urban Design Conference, Sydney, Australia, 21 - 23 August.

Mulholland Research and Consulting (2004) Attitudes and Decision Making Among Home Buyers. Report on quantitative research findings. Prepared for CABE, WWF and HBOS.

National Rivers Authority. (1994). Water - Natures Precious Resource: An Environmentally Sustainable Resource Development Strategy for England and Wales. London. National Rivers Authority.

Nolde, E. (2006) Possibilities of rainwater utilization in densely populated areas including precipitation runoffs from traffic surfaces. Desalination Vol 215. pp 1 - 11.

ODPM (2005) A sustainability impact study of additional housing scenarios in England. London. ODPM.

ODPM. (2006) $14^{\text {th }}$ March Statistical Release: New Projections of Households for England and the Regions to 2026. Office of the Deputy Prime Minister. [online] Available at:

http://www.communities.gov.uk/documents/statistics/pdf/1089390.pdf. [Accessed 30th April 2009].

Paciarotti, C., Ciarapica, F.E. and Giacchetta, G. (2007) Analysis of rainwater collection systems: an overview of the Italian situation. In Proceedings of the Rainwater and Urban Design Conference, Sydney, Australia, $21-23$ August.

Read, C. (2005) Better Buildings: Designing for water efficiency. London. Green Alliance.

Rose, J,B. (2007) Water Reclamation, Reuse and Public Health. Water Science and Technology. Vol,55. Iss, 1-2. pp275-282.

Scott, R.S. and Waller, D.H. (1991) Development of guidelines for rainwater cistern systems in Nova Scotia. In Proceedings of $5^{\text {th }}$ International Conference on Rainwater Catchment Systems, Keelung, Taiwan, 4-10 August.

Smerdon, T. Wagget, R and Grey, R. (1997) Sustainable Housing - options for independent energy. water supply and sewerage. BSRIA. Berkshire.

SPONGE. (2005) The gaps in the existing case for building sustainable homes to encourage sustainable lifestyles. London. SPONGE.

Suzenet, G. Tal, A. and Boymanns, D. (2002) Sustainable water management for the city: Technologies for improving domestic water supply. Built Environment. Vol,28. Iss,2. pp138-151.

Townsend, A.R., Jowett, E.C., LeCrow, R.A., Waller, D.H., Paloheimo, R., Ives, C., Russell, P. and Liefhebber, M. (1997). Potable water treatment and reuse of domestic wastewater in the CMHC Toronto 'Healthy House'. American Soc. For Testing and Materials Vol, 1324, pp 176 - 187.

Tranter, M (2005) Australian approaches to governance in sustainable urban housing: Energy and Water. pp392-406 [online] Available at: http://www.env.leeds.ac.uk/ hubacek/leeds04/6.6TranterAustralian\%20approaches\%20paper.pdf. [Accessed 30th April 2009]. 
Virllarreal, E.L. and Dixon, A. (2005) Analysis of a rainwater collection system for domestic water supply in Ringdansen, Norrkoping, Sweden. Building and Environment. Vol, 40. pp 1174 - 1184.

UK house Builders directory http://www.propertydata.com/index.asp?page=publication.asp\&pub=HBDR [Accessed 30 ${ }^{\text {th }}$ April 2009]. 